\title{
PROTEIN DIGESTIBILITY AND AMINO ACID CONTENT OF MALAYSIAN LOCAL EGG PROTEIN PREPARED BY DIFFERENT METHODS
}

\author{
Marwan Msarah*, Ahmed Alsier \\ School of Chemical Science and Food Technology, Faculty Science \& Technology, University Kebangsaan Malaysia, 43600 UKM, Bangi, Malaysia \\ *Corresponding author email: marwan_masar21@yahoo.com.
}

This is an open access article distributed under the Creative Commons Attribution License, which permits unrestricted use, distribution, and reproduction in any medium, provided the original work is properly cited.

\section{ARTICLE DETAILS}

\section{Article History:}

Received 12 November 2017 Accepted 12 December 2017 Available online 1 January 2018

\begin{abstract}
The purpose of the study was to elucidate the effect of preparation methods hard-boiled half-boiled \& raw on the digestibility of protein and the amino acid composition as well as the protein quality of nutrient enriched Malaysian eggs. The amino acid content was determined using HPLC. All The essential and the non-essential amino acids as well as the individual amino acid was significantly increased as result of half-boiled and decrease as result of hardboiled methods. The PH value of hard-boiled, half-boiled \& raw were $7.03 \pm 0.09,6.795 \pm 0.06,7.305 \pm 0.13$ respectively, whereas the casein scores $5.53 \pm 0.04$ as the lowest PH value. In vitro digestibility of protein value of hard-boiled, half-boiled \& raw were $76.24 \pm 2.8,81.54 \pm 1.8,70.03 \pm 4.4$ respectively, whereas the casein scores $99.08 \pm 2.4$ as the highest digestibility value. Among the eggs samples, half-boiled had the highest digestibility at $81.54 \pm 1.8$, followed by hard-boiled at $76.24 \pm 2.8$. Whereas, the raw egg had the lowest digestibility value at $70.03 \pm 4.4$. Based on these results there were significant differences $(p<0.05)$ among the egg samples compare to casein.
\end{abstract}

\section{KEYWORDS}

Amino acid score, HPLC, protein digestibility, casein.

\section{INTRODUCTION}

Egg traditionally has been used for breakfast, home meal preparation, and baking and it is highly nutritious. It supplies a large amount of complete high-quality protein and provides significant amounts of several vitamins and minerals [1, 2]. Egg is an important animal protein, it contains all the essential amino acids needed for human body and it is suitable for people for all ages [3-6].

Based on Malaysia Food Balance Sheet, egg is a common food among Malaysians, whose consumption was quite high reaching up to $3.8 \mathrm{~g}$ protein a day per capita supply [7-9]. In Malaysia, many cooking methods are used in preparing meals with egg such as boiling, half-boiling, frying, and steaming etc. Although eggs contain about $74 \%$ water, they are a rich source of protein needed for human growth.

The egg protein is high quality, so it is commonly used as a standard for measuring the nutritional quality of other food proteins [4,5]. Egg protein has the perfect amino acid composition and was used as the reference protein for biological evaluation and assessment of amino acid patterns $[10,11]$.

The digestibility of protein is affected by its state of processing before ingestion. Both an enhanced and a reduced protein digestibility have been observed after food processing (e.g., boiling, drying, deep-freezing or microwave-heating) [10]. Such treatments may cause modification of the nutritional value of proteins digestibility. Therefore, the aim of this study was to elucidate the effects of preparation methods (half-boiling, hardboiling \& raw) on protein digestibility and amino acid content of Malaysian local eggs (nutrient enriched eggs).

\section{METHODOLOGY}

\subsection{Sample collection}

Nutrient enriched eggs purchased from local supermarket at Kajang, Malaysia. Half of the samples were used for the amino acid content and the other half were used for the digestibility of the protein in eggs. Samples were placed in clean dry box and transported to the laboratory.

\subsection{Sample preparation}

I. Raw eggs: Shells was removed.

II. Hard-boiled eggs: Eggs were boiled in tap water at water boiling point $100^{\circ} \mathrm{C}$ for 8 to 10 minutes in order to obtain hard-boiled eggs.

III. Half-boiled eggs: Eggs were boiled in tap water at water boiling point $100^{\circ} \mathrm{C}$ for 4 to 6 minutes.

2.3 Amino acid composition freeze drying

All samples were placed in clean containers separately and sealed with Parafilm then were undergoing freeze drying to for three days.

\subsection{Dilapidation}

In order to remove lipids from the samples chloroform and methanol method was used as follow. $40 \mathrm{ml}$ of chloroform and $20 \mathrm{ml}$ of methanol were added to each sample and mixed for 3 to 5 minutes and left till the separation was clear between protein and lipids. Rotary evaporator was used to remove the chloroform and the methanol from the samples. The amino acids content of the samples was analyzed and quantitatively determined using the HPLC.

\subsection{Protein digestibility}

Four enzymes were utilized, Papain (papaya), bromaline (pineapple), flavourzyme \& casein (control). Distilled water, water bath, stopwatch \& scale. Jacketed reaction vessel beakers to determent the PH value.

Weight samples

I. Hard-boiled:

$1 \mathrm{~g}$ sample $=0.537 \mathrm{~g}$ of protein $=537 \mathrm{mg}$.

$\underline{1000 \mathrm{mg} \text { sample }}=\underline{537 \mathrm{mg}}=1.9 \mathrm{mg}$ sample $\times 6.25 \mathrm{mg}$ protein $\times 10=118.75 \mathrm{mg}$

$$
537 \mathrm{mg} \quad 5 \overline{537 \mathrm{mg}}
$$


II. Half-boil:

$1 \mathrm{~g}$ sample $=0.551 \mathrm{~g}$ of protein $=551 \mathrm{mg}$.

$\underline{1000 \mathrm{mg} \text { sample }}=\underline{551 \mathrm{mg}}=1.8 \mathrm{mg}$ sample $\times 6.25 \mathrm{mg}$ protein $\times 10=113.4 \mathrm{mg}$ $551 \mathrm{mg} \quad 5 \overline{551 \mathrm{mg}}$

III. Raw egg:

$1 \mathrm{~g}$ sample $\quad=0.565 \mathrm{~g}$ of protein $=565 \mathrm{mg}$

$\underline{1000 \mathrm{mg} \mathrm{sample}}=\underline{565 \mathrm{mg}}=1.7 \mathrm{mg}$ sample $\times 6.25 \mathrm{mg}$ protein $\times 10=110.06 \mathrm{mg}$ $565 \mathrm{mg} \quad \overline{565 \mathrm{mg}}$

All the samples (hard-boiled, half-boiled \& raw) were placed in the tubes $\& 10 \mathrm{ml}$ of distilled water were added to each. PH was adjusted to 8 (HCL to reduce \& $\mathrm{NaOH}$ to increase). (0.001N HCl, $0.01 \mathrm{~N} \mathrm{HCl}, 0.1 \mathrm{~N} \mathrm{Nacl}, 0.05 \mathrm{~N}$ $\mathrm{NaOH} \& 0.1 \mathrm{~N} \mathrm{NaOH})$. All the samples were placed into the fridge for 1 hour.

\subsection{Enzymes preparation}

Bromelain (40mg), papain (41.8mg), flavourzyme (13mg) \& casein $(62.50 \mathrm{mg})$ as control. Bromelain was mixed with papain and added to $10 \mathrm{ml}$ of distilled water. PH was adjusted to 8 \& placed into the fridge for 1 hour. Flavourzyme was added to $10 \mathrm{ml}$ of distilled water. PH was adjusted to $8 \&$ placed into the fridge for 1 hour. Casein (control) was added to $10 \mathrm{ml}$ of distilled water. PH was adjusted to 8 \& placed into the fridge for 1 hour.

$1 \mathrm{ml}$ of the mixed (bromelain \& papain) was added to each sample (hardboiled, half-boiled, raw \& casein). 1 capsule was added to each sample and placed them into the jacketed reaction vessel at $37^{\circ} \mathrm{C}$ for 10 minutes. $1 \mathrm{ml}$ of the flavourzyme was added to each samples \& placed them in the water bath at $55^{\circ} \mathrm{C}$ for 19 minutes. the samples were placed directly into the jacketed reaction vessel after water bath for 1 minute \& noted down the $\mathrm{PH}$ value.

\subsection{Statistical Analysis}

All the samples were carried out at least in duplicate. Mean and standard deviation were calculated. Data obtained was analysed to see the differences in the amino acid content and the digestibility of protein in hard-boiled, half-boiled, raw and casein (control). Pearson's correlation coefficients were performed to compare the data and the significant level for all test was set at $\mathrm{p}<0.05$.

\section{RESULTS}

\subsection{Essential amino acid content in egg samples}

The essential amino acids that generally regarded as essential for humans are: phenylalanine, valine, threonine, tryptophan, isoleucine, methionine, leucine and lysine. The result of essential amino acid composition of the three egg samples prepared by different methods (raw, hard and half boiling) are presented in Table 1.

The study indicated that lysine, leucine, phenylalanine, and valine gave the highest amino acid content. All essential amino acids were significantly increased after half-boiling and decrease after hard-boiling treatments. Leucine acid content in raw was 6.492 and increase to 6.943 after halfboiling treatment. Whereas, after hard-boiling treatment was decrease to 5.945. And the same happened for the rest amino acids. It also shows that the lowest amino acid content was in methionine and histidine acids. Methionine acid content were $2.717,2.871$ and 2.554 respectively, and histidine acid content were 1.912, 2.089 and 1.777 respectively.

Table 1: Essential amino acid content in egg samples

\begin{tabular}{|c|c|c|c|}
\hline $\begin{array}{l}\text { Essential amino } \\
\text { acid }\end{array}$ & raw & half boil & hard boil \\
\hline Methionine & 2.717 & 2.871 & 2.554 \\
\hline Valine & 5.072 & 5.569 & 4.794 \\
\hline Isoleucine & 4.051 & 4.385 & 3.765 \\
\hline Leucine & 6.492 & 6.943 & 5.945 \\
\hline Phenylalanine & 4.320 & 4.628 & 3.949 \\
\hline Tyrosine & 3.387 & 4.157 & 2.004 \\
\hline
\end{tabular}

\begin{tabular}{llll}
\hline Histidine & & & \\
Lysine & 1.912 & 2.089 & 1.777 \\
& 5.119 & 5.596 & 4.917 \\
\hline
\end{tabular}

\subsection{Non-essential amino acid content in egg samples}

Table 2 represents the content of non-essential amino acids in the studied egg samples. The total content of all amino acids was significantly different among different egg samples, and that preparation method affects significantly on individual and total amino acids of egg samples. The total content of all amino acids as well as the individual amino acid was significantly increased as result of half-boiling and decrease as result of hard-boiling methods. From this table aspartic, glutamic and serine acids showed higher amino acid content. Aspartic acid content in raw, halfboiled and hard-boiled were $7.551,8.450$ and $6.997 \mathrm{mg} / \mathrm{g}$ protein respectively, and glutamic acid were $9.197,10.032$ and 8.679 respectively, and for serine acid were 5.332, 5.746 and 4.943 respectively. Whereas, glycine and proline showed the lowest amino acid content. Glycine acid content in raw, half-boiled and hard-boiled were 2.628, 2.089 and 2.493 respectively, and proline acid were $2.764,2.926$ and 2.591 respectively.

Table 2: Non-essential amino acid content in egg samples

\begin{tabular}{llll}
\hline $\begin{array}{l}\text { Non-essential } \\
\text { amino acid }\end{array}$ & raw & half boil & hard boil \\
\hline Aspartic acid & 7.551 & 8.450 & 6.997 \\
Glutamic acid & 9.197 & 10.032 & 8.679 \\
Serine & 5.332 & 5.746 & 4.943 \\
Glycine & 2.628 & 2.089 & 2.493 \\
Arginine & 4.417 & 4.972 & 4.163 \\
Alanine & 3.849 & 4.556 & 3.789 \\
Proline & 2.764 & 2.926 & 2.591 \\
Tyrosine & 3.387 & 4.157 & 2.004 \\
\hline
\end{tabular}

\section{DISCUSSION}

\subsection{Digestibility of eggs protein}

\subsubsection{PH value}

The PH value of hard-boiled, half-boiled, and raw \& casein (control) samples is shown in Table 3. From this table, the PH value of hard-boiled, half-boiled, raw \& casein samples were in the range of $7.03 \pm 0.09$, $6.795 \pm 0.06,7.305 \pm 0.13 \& 5.53 \pm 0.04$ respectively. The highest $\mathrm{PH}$ value among the samples was found in raw egg at $7.305 \pm 0.13$ followed by hardboiled at $7.03 \pm 0.09$. The lowest PH value was found in casein (control) at $5.53 \pm 0.04$ followed by half-boiled at $6.795 \pm 0.06$. Based on these results there were significant differences $(\mathrm{p}<0.05)$ of $\mathrm{PH}$ value among the egg samples compare to casein.

Table 3: PH value of three egg samples prepared and casein (control)

\begin{tabular}{ll}
\hline Sample & PH value \\
\hline Hard-boiled & $7.03 \pm 0.09$ \\
Half-boiled & $6.795 \pm 0.06$ \\
Raw egg & $7.305 \pm 0.13$ \\
Casein & $5.53 \pm 0.04$
\end{tabular}

*Means \pm standard deviation of two determinations. 


\subsubsection{The digestibility values}

In vitro digestibility of the protein samples were calculated using the following equation (\% Digestibility $=234.84-22.56 \mathrm{X}$ ), where $\mathrm{X}$ is the $\mathrm{PH}$ at 1 minute $[12,13]$. The protein digestibility of the egg enriched nutrition hard-boiled, half-boiled, raw \& casein (control) obtained with the enzymatic assay are shown in table 4 . From this table, the digestibility of protein value of hard-boiled, half-boiled, raw \& casein samples were in the range of $76.24 \pm 2.8,81.54 \pm 1.8,70.03 \pm 4.4,99.08 \pm 2.4$ respectively.

The casein reference sample had the highest digestibility value of $99,08 \%$. Among the eggs sample, half-boiled egg had the highest digestibility at $81.54 \%$, followed by the hard-boiled at $76.24 \%$. The raw egg had the lowest digestibility at $70.03 \%$. The digestibility of the casein is significantly higher than other samples because its contains highly protein, the lower the $\mathrm{PH}$ the higher the digestibility. Based on these results there were significant differences $(p<0.05)$ of the digestibility among the egg samples compare to casein $[14,15]$.

Table 4: Digestibility value of three egg samples and casein (control)

\begin{tabular}{ll}
\hline Samples & Digestibility \\
\hline Hard-boiled & $76.24 \pm 2.8$ \\
Half-boiled & $81.54 \pm 1.8$ \\
Raw egg & $70.03 \pm 4.4$ \\
Casein & $99.08 \pm 2.4$ \\
\hline
\end{tabular}

*Means \pm standard deviation of two determinations.

\section{CONCLUSION}

The effects of hard-boiling, half-boiling \& raw on the protein digestibility and amino acid composition of nutrient enriched eggs were studied. Mildheat treatments in the presence of water can significantly improve the protein's nutritional value in some cases. half-boiling condition can increase or preserve the amino acid in eggs. There were significant differences $(\mathrm{p}<0.05)$ of $\mathrm{PH}$ value in raw, among the egg samples compare to casein. Also, there were significant differences $(p<0.05)$ of digestibility value among the eggs. In other words, Half-boiled scored the highest digestibility value and amino acid contents among the eggs samples. The Reduce in protein digestibility and the amino acid contents is primarily associated with excessive heat as well as raw.

\section{REFERENCES}

[1] Gutierrez, M.A., Takahashi H., Juneja L.R. 1996. Nutritive evaluation of hen eggs. In: Hen eggs their basic and applied science. Eds T. Yamamoto, L.R. Juneja, H. Hatta, M. Kim. CRC Press Boca Raton, 25-35.
[2] Lifschitz, C. 2012. New actions for old nutrients. Acta Scientiarum Polonorum Technologia Alimentaria, 11 (2), 183-192.

[3] Friedman, M. 1996. Nutritional value of proteins from different food sources. Journal of Agricultural and Food Chemistry, 44 (1), 6-29.

[4] Sakanaka, S., Kitahata, K., Mitsuya, T., Gutierrez, M.A. 2000. Protein quality determination of delipidated egg-yolk. Journal of Food Composition and Analysis, 13 (5), 773-781.

[5] Cook, F., Briggs, G.M. 1977. Nutritive value of eggs. In: Eggs science and technology. The Avi publishing company, 92-101.

[6] Babji, A.S. 1989. Measuring protein digestibility using an enzymatic in vitro technique. Proc. Nutr. Soc. Mal., 4, 53-58.

[7] FAO. 2001. Food balance sheet. Food and Agriculture Organization of United Nation. Rome, Italy.

[8] World Health Organization. 1991. Protein Quality Evaluation: Report of the Joint FAO/WHO Expert Consultation, Bethesda, Md., USA 4-8 December 1989 (No. 51). Food \& Agriculture Org.

[9] US Department of Agriculture, Agricultural Research Service. 2016. USDA National Nutrient Database for Standard References, Release 28. Nutrient Data Laboratory Home Page. http://ndb.nal.usda.gov.

[10] Southgate, D.A.T. 2000. Human nutrition and diabetics. Churchill Livingstone, United Kingdom, 363-374.

[11] Hoppe, A. 2010. Examination of egg white proteins and effects of high pressure on select physical and functional properties. Dissertations and Theses in Food Science and Technology. Paper 7.

[12] O"ste, R.E. 1991. Digestibility of processed food protein. In: Nutritional and Toxicological Consequences of Food Processing (Friedman, M., ed.), Plenum Press, New York, NY, 371-388.

[13] Vachon, C., Gauthier, S., Charbonneau, R., Savoie, L., Parent, G., Provencher, P. 1987. Relationship between in vitro digestion of proteins and in vivo assessment of their nutritional quality. Reproduction Nutrition Development, 27 (3), 659-672.

[14] Yada, R.Y. (Ed.). 2017. Proteins in food processing. Woodhead Publishing.

[15] Chibnall, A.C., Rees, M.W., Williams, E.F. 1943. The total nitrogen content of egg albumin and other proteins. Biochemical Journal, 37 (3), 354. 